\title{
Preliminary Results of Effect of Rotational Grazing of Farmed Red Deer (Cerous elaphus) on the Biochemical Status of Soil
}

\author{
Barbara Futa $^{1}$ (D), Katarzyna Tajchman ${ }^{2, *(D)}$, Żaneta Steiner-Bogdaszewska ${ }^{3}$, Leszek Drozd ${ }^{2}$ \\ and Tomasz M. Gruszecki ${ }^{4}$ \\ 1 Institute of Soil Science, Environment Engineering and Management, University of Life Sciences in Lublin, \\ Leszczynskiego St. 7, 20-069 Lublin, Poland; barbara.futa@up.lublin.pl \\ 2 Department of Animal Ethology and Wildlife Management, Faculty of Animal Sciences and Bioeconomy, \\ University of Life Sciences in Lublin, Akademicka 13, 20-950 Lublin, Poland; leszek.drozd@up.lublin.pl \\ 3 Institute of Parasitology of the Polish Academy of Sciences, Research Station in Kosewo Górne, \\ 11-700 Mragowo, Poland; kosewopan@kosewopan.pl \\ 4 Institute of Animal Breeding and Biodiversity Conservation, Faculty of Biology, Animal Sciences and \\ Bioeconomy, University of Life Sciences in Lublin, Akademicka 13, 20-950 Lublin, Poland; \\ tomasz.gruszecki@up.lublin.pl \\ * Correspondence: katarzyna.tajchman@up.lublin.pl; Tel.: +48-81-445-6848
}

check for

updates

Citation: Futa, B.; Tajchman, K.; Steiner-Bogdaszewska, Ż.; Drozd, L.; Gruszecki, T.M. Preliminary Results of Effect of Rotational Grazing of Farmed Red Deer (Cervus elaphus) on the Biochemical Status of Soil.

Agronomy 2021, 11, 558.

https://doi.org/10.3390/

agronomy 11030558

Academic Editor: Eli Zaady

Received: 28 February 2021

Accepted: 12 March 2021

Published: 15 March 2021

Publisher's Note: MDPI stays neutral with regard to jurisdictional claims in published maps and institutional affiliations.

Copyright: (c) 2021 by the authors. Licensee MDPI, Basel, Switzerland. This article is an open access article distributed under the terms and conditions of the Creative Commons Attribution (CC BY) license (https:/ / creativecommons.org/licenses/by/ $4.0 /)$.
Abstract: The aim of the study was to identify the trends and dynamics of changes in the chemical and biochemical properties of soil induced by rotational grazing of farmed deer. Soils $\mathrm{pH}$ and the content of mineral nitrogen forms, total nitrogen, and organic carbon were determined in the study and the activity of three soil enzymes. The monitored soils were slightly acidic and neutral, with $\mathrm{pH}$ in $1 \mathrm{~mol} \mathrm{KCldm}^{-3}$ ranging from 6.37 to 7.03 . The contents of content of organic carbon, total nitrogen in the monitored soils were in the range of $9.42-19.37 \mathrm{gkg}^{-1}$ and $1.13-2.24 \mathrm{gkg}^{-1}$, respectively, while the contents of $\mathrm{N}_{-} \mathrm{NH}_{4}{ }^{+}$ and $\mathrm{N}_{-\mathrm{NO}_{3}}{ }^{-}$of $1.34-7.08 \mathrm{mgkg}^{-1}$ and $102.8-619.5 \mathrm{mgkg}^{-1}$, respectively. The mean levels of nitrate nitrogen in the pasture soils were lower than that in the mown soil. The soils from the pastures were characterized by a higher level of available phosphorus, potassium, and magnesium forms than the mown soil. In the deer grazing areas, the activity of all enzymes was clearly higher than in the soil from the control plot. The results of the present pilot study have demonstrated a positive effect of cervid grazing on the biochemical parameters of the soil environment.

Keywords: free-range grazing; cervids; soil enzymes; biogenic substances; nitrogen; carbon

\section{Introduction}

In recent years, there has been a rapid decline in biodiversity caused by the human demographic success. The rapid growth of the human population leads to e.g., massive exploitation of natural resources, global warming, soil degradation, species extinction, and an unprecedented ecosystem decline [1,2]. One of the instruments for biodiversity protection is livestock grazing [3,4]. Besides its low costs, free-range grazing contributes to limitation of the expansion of forest and scrub communities, which otherwise leads to retreat and disappearance of ecosystems with their valuable fauna and flora species. Grazing also contributes to optimization of economic and protection-related activities. Many studies have confirmed the positive effect of farmed animal grazing, i.e., sheep [5-8], cattle $[7,9]$, or horses $[5,8,10,11]$ on preservation of the biodiversity of areas covered by various forms of protection. In another research grazing has been found to have negative effects on ecosystem [12,13]. Farmed animal grazing can soil degraded [14], reduced the density and biomass of plant and animal species and limited biodiversity [15].

Cervid species can similarly be used for protection of habitats through extensive grazing. The scientific literature does not provide information on the role of these ruminants in the protection of biodiversity. Deer farms are present nowadays on a large scale in New Zealand and, to a lesser extent, in Europe, North America, Australia and even 
in tropical regions, such as Mauritius and New Caledonia, and deer are farmed under a variety of conditions, ranging from extensive to intensive systems [16,17]. The most widespread deer species in modern deer farms are red deer (Cervus elaphus), and fallow deer (Dama dama) $[16,18]$. The impact of these animal species on the soil environment may be of interest to nature managers.

The acreage of pastures in Europe has decreased considerably during the last several decades as a result of changes in land use, including the abandonment of farmed animal grazing, secondary succession, or the reforestation of land on poor soils [7,10]. This changes have exert an impact on of the soil, which plays a major role in maintaining ecosystem biodiversity. Consequently, unfavorable changes occur in the soil cover, e.g., reduction of biological activity, lower content of soil humus, and impoverishment of biological diversity. Habitats and their natural plant communities are dependent on soil properties and prevailing climatic conditions. In turn, soil quality and health depend on the course of organic matter transformations related mainly to microorganisms and released enzymes as well as the rate of biogeochemical alterations in the circulation of elements [19-21]. The activity of soil enzymes is regarded as one of the most sensitive indicators of ecosystem functioning. It reflects both the trends and nature of biogeochemical processes and changes in the biological and physicochemical properties of soils [22,23]. Assessment of the environment condition based on enzymatic assays helps to express numerically the effect of numerous factors and to determine parameters that cannot be evaluated otherwise, e.g., elements of cellular metabolism. An unquestionable advantage is also the possibility of conducting series of analyses [24,25].

Since cervid farming is regarded as an ecological activity [18,26], it has been hypothesized that grazing of these species may have a beneficial effect on the biochemical properties of soil and ecosystem biodiversity. The strategic goal of the present study was to identify the trends and dynamics of changes in the chemical and biochemical properties of soil induced by rotational grazing of farmed deer. Assessment of the impact of extensive grazing of farmed animals on the biological status of soils facilitated measurement of the activity of a number of soil enzymes: dehydrogenases, neutral phosphatase, and urease. These enzymes are directly involved in the transformation of soil organic matter and react markedly to the effects of stress factors. The practical aim was to use enzyme assays for rapid assessment of the ecobiochemical status of soils.

\section{Materials and Methods}

\subsection{Experimental Design}

The research was carried out at the Research Station of the Institute of Parasitology, Polish Academy of Sciences, Kosewo Górne (Region of Warmia and Mazury; Poland; $53^{\circ} 48^{\prime} \mathrm{N} ; 2^{\circ} 23^{\prime} \mathrm{E}$, EPSG:3857). It was established in 1984 as a pioneering research unit for deer farming and breeding. This oldest deer farm in Poland is located in the north-eastern part of the country, which is regarded as an unpolluted zone, as it is located far from large industrial and urban centers [27]. The farm is surrounded by a large forest complex. Red deer (Cervus elaphus), sika deer (Cervus nippon), and European fallow deer (Dama dama), in total approximately 500 animals, are reared in the extensive system in 100-ha pasture pens [28]. The animals on the farm are grazed rotationally in the pens at a density and nutrition supply recommended by FEDFA [29] and Mattiello [26]. Prior to the beginning of the vegetation season, Amigo ammonium nitrate fertilization is applied at a dose of $200 \mathrm{~kg} / \mathrm{ha}$ in the farm pastures in March every year.

The research area is located in Eastern Europe, the sub-area of the East European Lowlands, the Eastern Baltic-Belarusian Lowlands province, the Eastern Baltic Lake District sub-province, the Masurian Lake District macroregion, and the Mragowo Lakeland mesoregion. This region is influenced by a continental climate. Mragowo Lakeland is characterized by the highest values of cloud cover and the highest wind speed. Besides the mountain regions, it is one of the coldest regions of Poland. According to the data of the Institute of Meteorology and Water Management National Research Institute (IMWM- 
NRI), the average annual air temperature in the study area is $+6.6{ }^{\circ} \mathrm{C}$. The highest average maximum temperatures are usually recorded in July, with an average monthly temperature of $+17.4{ }^{\circ} \mathrm{C}$. February is the coldest month with an average temperature of $-4.8^{\circ} \mathrm{C}$. The average annual precipitation is $576 \mathrm{~mm}$, with the minimum level in March $(23 \mathrm{~mm})$ and the maximum in July $(78 \mathrm{~mm})$. The length of the growing season is approx. 209 days, and snow cover persists for approx. 80 days on average. The impact of the surface waters is reflected in the higher air humidity. On average, there are 38 days with fog per year. The sunniest days are noted in May, June, and September, while the least sunny ones are recorded in November and December [30]. The forest cover in Mragowo District is 31.5\%. In turn, forests account for $31.2 \%$ in the Warmian-Masurian Voivodeship and $30.9 \%$ in Poland [31].

The experiment was established on Albic Podzol (PZal) formed from glaciofluvial fine-grained loamy sand [32].

\subsection{Sampling}

The soil material was collected for laboratory analyses in two terms: in spring (April 2018) and autumn (October 2018) in periods of stable weather. At that time, the soil was in a dynamic equilibrium state, which maintained the biochemical processes within the moderate intensity limits. The experiment has been set up in a randomized block design in three replicates. The pasture for deer grazing was divided into pens where the animals stayed rotationally. Soil was sampled from the following pasture pens: (1) summer pen (S) - before and after the end of summer grazing, (2) winter pen (W) - after the end of winter grazing and in autumn, (3) sown pens (SG)-before and after the end of summer grazing. The selection of these terms and objects were prompted by the fact that deer stay in larger pens and feed only on its vegetation in summer (April-October) but receive concentrated and roughage diets in winter (November-March), as the control group described by Tajchman et al. [33]. The sown pen (SG) was supplemented with the Granum universal grass mixture (FN Granum ${ }^{\circledR}$ ) before the beginning of the vegetation season (March) in order to increase the yield and, hence, provide appropriate quality of the animal diet. A 0.5-ha mown meadow located in close proximity to the deer farm beyond the grazing range was the reference object (control-Co). The characteristics of the pens are presented in Table 1. The soil was sampled for laboratory analysis in five points on each surface. Each sample was individually averaged within the range of the studied areas and was assayed in three replications. The samples were collected from a depth of $0-25 \mathrm{~cm}$ in the humus level. Soil samples intended for chemical and biochemical analyses were collected and stored in accordance with the principles specified by ISO 18400 [34].

Table 1. Characteristics of research objects.

\begin{tabular}{cccc}
\hline Pens & Summer (S) & Winter (W) & Sown Pen (SG) \\
\hline Area (ha) & 2.7 & 1.3 & 2.8 \\
Animal cast (number of animals) & 16 & 8 & 16 \\
Period of stay of animals & April-October & November-March & April-October \\
\hline
\end{tabular}

The chemical analyses consisted in determination of the following parameters: $\mathrm{pH}_{\mathrm{KCl}}$ with the potentiometric method for measurement of the $\mathrm{pH}$ of soil suspensions in a $1 \mathrm{~mol} \mathrm{dm}^{-3}$ $\mathrm{KCl}$ (1:2.5) solution in accordance with ISO 10390 [35], the content of mineral nitrogen forms, i.e., ammonium nitrogen $\left(\mathrm{N}^{-} \mathrm{NH}_{4}{ }^{+}\right)$and nitric nitrogen $\left(\mathrm{N}^{-\mathrm{NO}_{3}}{ }^{-}\right)$in accordance with ISO 14255 [36], total nitrogen content (TN) [37], and organic carbon content (TOC) [38]. The content of available phosphorus, potassium, and magnesium forms was determined with the use of the Egner Riehm method in an accredited laboratory (PN-R-04023 [39] $\left(\mathrm{P}_{2} \mathrm{O}_{5}\right)$; PN-R-04022 [40] $\left(\mathrm{K}_{2} \mathrm{O}\right)$; PN-R-04020 [41] (Mg)).

The methodology for determination of soil enzymatic activity was based on a detailed study conducted by Schinner et al. [42] and Dick [22]. The activity of three soil enzymes, i.e., dehydrogenases, neutral phosphatase, and urease, was determined. These enzymes 
are directly involved in the biogeochemical cycle of carbon (dehydrogenase), phosphorus (neutral phosphatase), and nitrogen (urease) in the environment. They react clearly to the action of stressors, and the magnitude of changes in their activity is related to the intensity of stress factors [21]. The classification of the soil enzymes tested, their abbreviations, units used to present the analytical data, as well as substrates and products used in the assays are presented in Table 2. Activity of dehydrogenases (ADh) was determined by Thalmann's method [42] using a 1\% solution of 2,3,5-triphenyl tetrazolium chloride (TTC) as a substrate. Determination of phosphatase activity (APh) was performed according to Tabatabai and Bremner [42] using a $0.8 \%$ disodium $p$-nitrophenyl phosphate solution as a substrate in buffer $\mathrm{pH}$ 7.0. Urease activity (AU) was determined following Zantua and Bremner [42] using a 2.5\% urea solution as a substrate. The activities of the enzymes were determined using a CECIL CE 2011 spectrophotometer at the following wavelengths: $\lambda=485 \mathrm{~nm}$ for dehydrogenases, $\lambda=410 \mathrm{~nm}$ for phosphatase, and $\lambda=410 \mathrm{~nm}$ for urease.

Table 2. Determination of the activity of soil enzymes.

\begin{tabular}{|c|c|c|c|c|c|}
\hline Enzymes & EC & Acronym & Substrate Name & Product Name & Unit Name \\
\hline Dehydrogenses & EC 1.1 & $\mathrm{ADh}$ & $\begin{array}{c}\text { 2,3,5-triphenyl tetrazolium } \\
\text { chloride (TTC) }\end{array}$ & triphenyl formazane (TPF) & mg TPF kg ${ }^{-1}$ DM $24 \mathrm{~h}^{-1}$ \\
\hline Phosphatase & EC 3.1.3 & $\mathrm{APh}$ & $\begin{array}{l}\text { disodium } p \text {-nitrophenyl } \\
\text { phosphate }\end{array}$ & p-nitrophenol (PNP) & $\mathrm{mmol} P N P \mathrm{~kg}^{-1} \mathrm{DM} \mathrm{h}^{-1}$ \\
\hline Urease & EC 3.5.1.5 & $\mathrm{AU}$ & urea & $\mathrm{N}-\mathrm{NH}_{4}{ }^{+}$ & $\mathrm{mg} \mathrm{N}-\mathrm{NH}_{4}{ }^{+} \mathrm{kg}^{-1} \mathrm{DM} \mathrm{h}^{-1}$ \\
\hline
\end{tabular}

\subsection{Statistical Analysis}

The differences between the four pasture pens and the two seasons were assessed using parametric tests (the Student's t-test and the ANOVA analysis of variance). Differences between individual pairs were checked with Tukey's RIR post-hoc test. A significance level of $p<0.05$ was assumed, which indicated the presence of statistically significant differences or correlations. The values of Pearson's linear correlation coefficient $(r)$ were calculated at a significance level $\alpha=0.05$ for all studied (parameters) dependences. The statistical analysis of the study results was performed using Microsoft Office Excel 2003 and Statistica PL 13.3 (TIBCO Software Inc., Tulsa, OK, USA).

\section{Results}

The physicochemical and biochemical properties of the soils in the research objects varied depending on the mode of land use, the duration of animal grazing, and the term of soil material sampling. The monitored soils were slightly acidic and neutral, with $\mathrm{pH}$ in $1 \mathrm{~mol} \mathrm{KCl} \cdot \mathrm{dm}^{-3}$ ranging from 6.37 to 7.03 (Table 3). The soils of the experimental pasture pens exhibited higher $\mathrm{pH}$ values than the soil from the control plot (Co-beyond the grazing range). The highest $\mathrm{pH}$ values were detected in the soil where the grass was supplemented with the mixture of grasses. The $\mathrm{pH}$ values were lower in autumn than in spring (Table 3).

The different habitat conditions generated by the mode of land use and the duration of animal grazing differentiated the content of organic carbon (TOC) and total nitrogen (TN) in the analyzed soils. The contents of TOC and TN in the monitored soils were in the range of $9.42-19.37 \mathrm{~g} \cdot \mathrm{kg}^{-1}$ and $1.13-2.24 \mathrm{~g} \cdot \mathrm{kg}^{-1}$, respectively (Table 3). The free-range grazing of the cervids had a beneficial effect on the total organic carbon and nitrogen contents in the soils of the $S$ and $\mathrm{W}$ pasture pens. This effect was most evident in pasture $\mathrm{W}$, where the content of these components in the grazed soil was significantly higher than in the Co soil (Table 3). This was caused by the supply of fresh organic matter to the soil environment with animal excrements and the full cover of the pen surface with grassy vegetation. No such tendency was observed in the case of pasture SG, which required supplementation with the mixture of grasses. The contents of TOC and TN in the soil from this pen were significantly lower than in the soil from the Co pen. In terms of the analysis dates, a statistically significant decrease in the content of these components in the S, SG, and Co soils was observed in autumn. An opposite trend was determined in the case of 
pen $\mathrm{W}$ (Table 3). The values of the TOC:NT ratio in the analyzed soils ranged from 8.2 to 9.9 (Table 3). The values of the TOC:NT ratio in the soil from pen SG were significantly higher than in the soils from the other experimental pens.

Table 3. Physicochemical properties of the soils tested.

\begin{tabular}{|c|c|c|c|c|c|c|c|}
\hline \multirow{2}{*}{ Plot } & \multirow{2}{*}{ Season } & \multirow{2}{*}{$\mathrm{pH}_{\mathrm{KCL}}$} & TOC & TN & \multirow{2}{*}{ TOC:TN } & $\mathrm{N}-\mathrm{NH}_{4}{ }^{+}$ & $\mathrm{N}-\mathrm{NO}_{3}{ }^{-}$ \\
\hline & & & \multicolumn{2}{|c|}{$\mathrm{g} \cdot \mathrm{kg}^{-1}$} & & \multicolumn{2}{|c|}{$\mathrm{mg} \cdot \mathrm{kg}^{-1}$} \\
\hline \multirow{2}{*}{$S$} & Spring & 6.88 & $19.37 \mathrm{a}$ & $2.24 \mathrm{a}$ & $8.7 \mathrm{a}$ & $7.08 \mathrm{a}$ & $255.1 \mathrm{a}$ \\
\hline & Autumn & 6.54 & $9.83 b$ & $1.15 b$ & $8.6 \mathrm{a}$ & $5.83 a$ & $102.8 \mathrm{~b}$ \\
\hline \multirow{2}{*}{$\mathrm{W}$} & Spring & 6.74 & $16.89 a$ & $1.98 \mathrm{a}$ & $8.5 a$ & $6.01 \mathrm{a}$ & $619.5 a$ \\
\hline & Autumn & 6.45 & $18.28 \mathrm{~b}$ & $2.14 \mathrm{a}$ & $8.5 a$ & $1.34 b$ & $172.8 \mathrm{~b}$ \\
\hline \multirow{2}{*}{ SG } & Spring & 7.03 & $14.41 \mathrm{a}$ & $1.45 \mathrm{a}$ & $9.9 a$ & $2.70 \mathrm{a}$ & $522.8 \mathrm{a}$ \\
\hline & Autumn & 6.59 & $9.42 b$ & $1.13 \mathrm{a}$ & $8.3 b$ & $4.81 \mathrm{~b}$ & $178.3 \mathrm{~b}$ \\
\hline \multirow{2}{*}{ Co } & Spring & 6.54 & $15.96 a$ & $1.84 \mathrm{a}$ & $8.7 \mathrm{a}$ & $3.04 \mathrm{a}$ & 617.9a \\
\hline & Autumn & 6.37 & $10.98 b$ & $1.34 b$ & $8.2 b$ & $5.19 b$ & $214.4 \mathrm{~b}$ \\
\hline$S$ & \multirow{4}{*}{$\begin{array}{l}\text { Average for } \\
\text { season }\end{array}$} & 6.71 & $14.60 \mathrm{a}$ & $1.70 \mathrm{a}$ & $8.7 \mathrm{a}$ & $6.46 a$ & $178.95 a$ \\
\hline $\mathrm{W}$ & & 6.60 & $17.59 \mathrm{~b}$ & $2.06 \mathrm{~b}$ & $8.5 \mathrm{a}$ & $3.68 \mathrm{~b}$ & $396.15 b$ \\
\hline SG & & 6.81 & $11.92 \mathrm{c}$ & $1.29 \mathrm{c}$ & $9.1 \mathrm{~b}$ & $3.76 \mathrm{~b}$ & $350.55 b$ \\
\hline $\mathrm{Co}$ & & 6.41 & $13.47 \mathrm{a}$ & $1.59 \mathrm{a}$ & $8.4 a$ & $4.12 \mathrm{c}$ & $416.15 c$ \\
\hline
\end{tabular}

TOC—-the content of organic carbon, TN—total nitrogen, a-c—different letters indicate significant difference at $p \leq 0.05$; $\mathrm{S}-$ summer pen; $\mathrm{W}$-winter pen; SG—-sown pen; $\mathrm{Co}$-control object.

The content of mineral nitrogen forms $\left(\mathrm{N}^{-\mathrm{NH}_{4}}{ }^{+}\right.$and $\left.\mathrm{N}^{-\mathrm{NO}_{3}}{ }^{-}\right)$in the analyzed soils varied depending on the mode of land use and the term of analyses. The contents of $\mathrm{N}-\mathrm{NH}_{4}{ }^{+}$and $\mathrm{N}-\mathrm{NO}_{3}{ }^{-}$in the soils of the monitored objects were in the range of $1.34-7.08 \mathrm{mg} \cdot \mathrm{kg}^{-1}$ and $102.8-619.5 \mathrm{mg} \cdot \mathrm{kg}^{-1}$, respectively (Table 3). The highest mean level of $\mathrm{N}-\mathrm{NH}_{4}{ }^{+}$was determined in the soil from pasture $\mathrm{S}$. In turn, the content of this component in the soils from pastures W and SG was significantly lower than that in the control soil. The mean levels of nitrate nitrogen $\left({\mathrm{N}-\mathrm{NO}_{3}}^{-}\right)$in the pasture soils were lower than that in the mown soil (Co), with the lowest content of this component determined in the pen $S$ soil. Significantly higher amounts of mineral nitrogen forms in the analyzed soils were determined in spring than in autumn. A reverse tendency was found only in the case of the ammonium nitrogen content in the SG and Co soils (Table 3).

The content of available phosphorus, potassium, and magnesium forms during the research period was $36-320 \mathrm{mg} \cdot \mathrm{kg}^{-1} ; 42-553 \mathrm{mg} \cdot \mathrm{kg}^{-1}$, and $48-136 \mathrm{mg} \cdot \mathrm{kg}^{-1}$, respectively (Table 4). The soils from the pastures were characterized by a higher level of available phosphorus, potassium, and magnesium forms than the mown soil (Co). The highest content of these components was determined in the winter pasture (Table 4). As in the case of nitrate nitrogen $\left(\mathrm{N}^{-\mathrm{NO}_{3}}{ }^{-}\right)$, the content of available $\mathrm{P}, \mathrm{K}$, and $\mathrm{Mg}$ forms was lower in autumn than in spring (Table 4).

The enzymatic activity of the analyzed soils varied significantly between the pastures. The trend and intensity of biochemical processes depended on the individual properties of the enzyme, the term of analyses, and the mode of land use in the object (Table 5). The following levels of the activity of dehydrogenases, neutral phosphatase, and urease were determined: $2.38-17.59 \mathrm{mg}$ TPF kg-1 $24 \mathrm{~h}^{-1}$, 30.72-235.87 mmol PNP kg-1 $\mathrm{h}^{-1}$, and 3.57-16.70 mg N-NH${ }_{4}{ }^{+} \mathrm{kg}^{-1} \mathrm{~h}^{-1}$, respectively (Table 5). In the deer grazing areas, the activity of all enzymes was clearly higher than in the soil from the Co plot. The highest enzyme activity was determined in the soil from pasture S (Table 5). In turn, the SG soil exhibited the lowest enzymatic activity, which was significantly lower than that in the control. This was probably associated with the significantly lower content of organic carbon and total nitrogen than that in the soils from the other study plots (Table 3). The present study demonstrated a close relationship between the dehydrogenases and phosphatase activity and the organic $\mathrm{C}$ and total $\mathrm{N}$ content in soil (Table 6). The analysis of the seasonal 
changes revealed lower activity of most enzymes in autumn than in spring. An increase in urease activity was recorded in the second analysis term only in the SG and Co soils

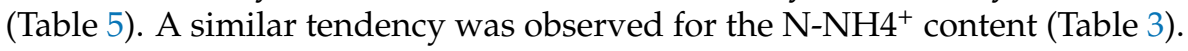

Table 4. The content of assimilable phosphorus $(\mathrm{P})$, potassium $(\mathrm{K})$ and magnesium $(\mathrm{Mg})$ forms in the soil.

\begin{tabular}{|c|c|c|c|c|}
\hline \multirow{2}{*}{ Pens } & \multirow{2}{*}{ Season } & $\mathbf{P}$ & $\mathbf{K}$ & Mg \\
\hline & & \multicolumn{3}{|c|}{$\mathrm{mg} \cdot \mathrm{kg}^{-1}$} \\
\hline \multirow{2}{*}{$S$} & Spring & 210 & 195 & 97 \\
\hline & Autumn & 136 & 114 & 61 \\
\hline \multirow{2}{*}{ W } & Spring & 320 & 553 & 136 \\
\hline & Autumn & 110 & 220 & 89 \\
\hline \multirow[b]{2}{*}{ SG } & Spring & 150 & 267 & 72 \\
\hline & Autumn & 114 & 201 & 56 \\
\hline \multirow{2}{*}{ Co } & Spring & 64 & 55 & 70 \\
\hline & Autumn & 36 & 42 & 48 \\
\hline $\mathrm{S}$ & \multirow{4}{*}{ Average for season } & 173 & 155 & 79 \\
\hline $\mathrm{W}$ & & 215 & 387 & 113 \\
\hline SG & & 132 & 234 & 64 \\
\hline Co & & 50 & 49 & 59 \\
\hline
\end{tabular}

Table 5. Enzymatic activity of soils.

\begin{tabular}{|c|c|c|c|c|}
\hline Pens & Season & $\mathrm{ADh}$ & APh & AU \\
\hline \multirow[b]{2}{*}{$S$} & Spring & $17.57 \mathrm{a}$ & $235.87 \mathrm{a}$ & $16.70 a$ \\
\hline & Autumn & $7.42 b$ & $98.43 b$ & $15.25 a$ \\
\hline \multirow{2}{*}{ W } & Spring & $17.59 \mathrm{a}$ & $209.12 a$ & $13.83 a$ \\
\hline & Autumn & $4.97 \mathrm{~b}$ & $72.81 b$ & $9.87 \mathrm{~b}$ \\
\hline \multirow{2}{*}{ SG } & Spring & $3.71 \mathrm{a}$ & $86.76 a$ & $3.57 \mathrm{a}$ \\
\hline & Autumn & $2.38 \mathrm{a}$ & $30.72 b$ & $7.41 \mathrm{~b}$ \\
\hline \multirow{2}{*}{ Co } & Spring & $10.75 a$ & $161.72 \mathrm{a}$ & $8.45 a$ \\
\hline & Autumn & $5.33 b$ & $44.01 b$ & $12.04 b$ \\
\hline$S$ & \multirow{4}{*}{ Average for season } & $12.50 \mathrm{a}$ & $167.15 a$ & $15.98 \mathrm{a}$ \\
\hline $\mathrm{W}$ & & $11.28 \mathrm{a}$ & $140.97 \mathrm{~b}$ & $11.85 b$ \\
\hline SG & & $3.05 b$ & $58.74 \mathrm{c}$ & $5.49 \mathrm{c}$ \\
\hline $\mathrm{Co}$ & & $8.04 \mathrm{c}$ & $102.87 \mathrm{~d}$ & $10.25 b$ \\
\hline
\end{tabular}

ADh—dehydrogenases in mg TPF kg ${ }^{-1} 24 \mathrm{~h}^{-1} ; \mathrm{APh}$-phosphatase in mmol PNP kg${ }^{-1} \mathrm{~h}^{-1}$; AU—urease in mg N-NH${ }_{4}^{+} \mathrm{kg}^{-1} \mathrm{~h}^{-1}$; $\mathrm{a}-\mathrm{d}$-different letters indicate significant difference at $p \leq 0.05$.

Table 6. Correlation coefficients between the activity of the examined enzymes and content of organic carbon (TOC), total nitrogen (TN) and $\mathrm{N}-\mathrm{NH}_{4}{ }^{+}$, and assimilable phosphorus $(\mathrm{P})$ and magnesium $(\mathrm{Mg})$ forms, $(\mathrm{N}=8)$.

\begin{tabular}{cccccc}
\hline Enzymes & TOC & TN & $\mathbf{N}_{-N H_{4}{ }^{+}}$ & $\mathbf{P}$ & $\mathbf{M g}$ \\
\hline Dehydrogenases & $0.63^{*}$ & $0.68^{*}$ & $\mathrm{~ns}$ & $0,71^{*}$ & $0.77^{* *}$ \\
Phosphatases & $0.72^{* *}$ & $0.72^{* *}$ & $\mathrm{~ns}$ & $0.68^{*}$ & $0.75^{* *}$ \\
Urease & $\mathrm{ns}$ & $\mathrm{ns}$ & $0.75^{* *}$ & $\mathrm{~ns}$ & $\mathrm{~ns}$ \\
\hline
\end{tabular}

${ }^{* *}$ significant at $\alpha=0.0001 .{ }^{*}$ significant at $\alpha=0.001 . \mathrm{ns}=$ not significant at $p>0.05$.

The present study indicated a significant relationship between the urease activity and the $\mathrm{N}_{-} \mathrm{NH}_{4}{ }^{+}$content in soil (Table 6). In turn, the activity of dehydrogenases and phosphatase exhibited a significant positive correlation with the levels of TOC, TN, and available $\mathrm{P}$ and $\mathrm{Mg}$ forms (Table 6). This proves that the supply of biogenic substances significantly stimulates the activity of soil enzymes. 


\section{Discussion}

Soil is an important component serving a variety of functions in the ecosystem. It is responsible for e.g., the ecochemical status of the environment as a natural buffer degrading xenobiotic compounds. Most importantly for animal welfare, it is a medium for plant growth and development [43]. Appropriate content of macro- and microelements in soil partly affects their content in green fodder [44,45]. The present results demonstrated differences in the physicochemical and biochemical parameters of the soils from the research plots associated with the mode of land use, the duration of animal grazing, and the analysis term. The increase in the value of $\mathrm{pH}$ of the pasture soils was related to microbial decomposition of uric acid excreted by animals. Ammonia, which forms $\mathrm{NH}_{4} \mathrm{OH}$ in the soil solution, is the main end product of the conversion of uric acid and its salts [46]. Additionally, animal feces are rich in alkaline elements [47,48]. The upward trend in the $\mathrm{pH}$ value in the livestock grazed soil has also been confirmed by other authors, e.g., Futa et al. [5] and Hao and He [9]. Grazing also influences the amount and composition of soil organic matter (SOM) through its effects on litter accumulation and decomposition [49]. The present study showed a beneficial effect of free-range grazing of cervids on the contents of organic carbon and total nitrogen. The effect has been confirmed by other investigators of free-range grazing of farm animals, e.g., Liu et al. [49], Li et al. [50], Bielińska et al. [51] and Galindo et al. [52]. The seasonal changes in the TOC and NT content in the analyzed soils may have been related to the rate of the decomposition of fresh organic matter supplied to the soil environment. The fluctuations in the content of organic carbon and total nitrogen in the soils may have been associated with the meteorological conditions as well. Elevated air temperature and soil desiccation are known to contribute to a faster increase in the amount of organic matter, whereas rainfalls and temperature drops reduce its levels [51]. Uric acid excreted by animals with feces is a source of heterogeneous nitrogen in grazed soils, regardless of the grazing system, soil type, and climate conditions [53-56]. In a urine patch, significant amounts of urinary $\mathrm{N}$ are rapidly converted into ammonium $\mathrm{N}$ in the soil and a substantial portion of the urine-derived ammonium $\mathrm{N}$ is gradually converted into nitrate $\mathrm{N}$ [57]. The content of nitrogen nitrate in the soils analyzed in the present study was several times higher than that of the ammonium form. The $\mathrm{pH}$ value of the soil environment is an important determinant of the relationships between both forms of mineral nitrogen in soils. The slightly acidic or neutral $\mathrm{pH}$ of the analyzed soils may have contributed to intensification of the rate of microbial oxidation of ammonium ions. The reduction of the content of these components in autumn was associated with the uptake thereof by plants during the growing season, leaching from the top layer of the soil profile

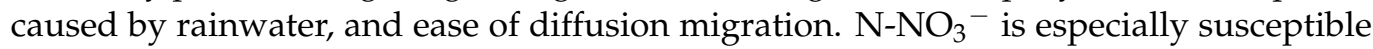
to migration with water [57]. The increase in the content of macroelements in the deer pasture soils was induced by the supply of fresh organic matter to the soil environment with animal feces. The results of investigations conducted by Li at al. [50] in an alpine meadow on the Tibetan Plateau demonstrated that grazing had a significant positive effect on soil properties, i.e., the soil moisture content, soil organic carbon concentration, soil total nitrogen concentration, soil available nitrogen, soil total phosphorus, and soil available phosphorus. Similarly, Galindo et al. [52] found that cattle grazing had a significant effect on soil properties, i.e., it increased the amount of available nutrients $(\mathrm{K}, \mathrm{Ca}, \mathrm{Mg})$ and TOC. The lower content of the available forms of $\mathrm{P}, \mathrm{K}$, and $\mathrm{Mg}$ observed in autumn in the present study may have been associated with the intensive uptake of these components by plants during the growing season [5].

The trend and intensity of the changes in the enzyme activity depended on the specific properties of each enzyme. This is associated with the content of specific substrates for enzymatic reactions in the soil and the individual sensitivity and resistance of enzymes to environmental and stress factors [20]. Soil microbial biomass, i.e., the living part of soil organic matter, functions as a transient nutrient sink and is responsible for decomposition and transformation of organic materials, which are mostly derived from aboveand below-ground plant residues, and release of nutrients from organic matter used by 
plants [49]. The organic matter content in soil is closely associated with the level of soil enzyme activity, as confirmed by many authors $[57,58]$. The high amount of organic matter in soil can increase biological activity by providing microorganisms with appropriate substrates $[49,52,59]$, which in turn can stimulate the synthesis of soil enzymes. Soil enzymes are produced mainly by soil microorganisms, although they can also be contained in plant root secretions $[20,60]$. Soil enzymatic activity can be regarded as a potentially sensitive indicator of changes in the soil environment induced by transformation of nutrients in the soil [60] and by livestock grazing [5]. As suggested by Dick et al. [61], the activity of soil enzymes should be the basic parameter for assessment of the quality of mineral soils, given their rapid response to environmental factors, compared to other soil properties. As shown by Ingram et al. [62], it is important to gain understanding of microbial communities and related processes to elucidate the $\mathrm{C}$ and $\mathrm{N}$ cycling. Furthermore, analysis of several enzyme activities involved in $\mathrm{C}, \mathrm{N}$, and $\mathrm{P}$ cycling can provide information about soil metabolic or functional responses to changes in management practices [63]. Herold et al. [57] found that intensive land use, including livestock grazing, resulted in a significant increase in the activity of specific enzymes involved in the $C$ cycle, regardless of the research region and soil properties, which may have exerted an effect on the decomposition of soil organic matter and the circulation of nutrients. However, these authors did not show an impact of livestock grazing on the activity of microorganisms and enzymes involved in the transformation of $\mathrm{N}$ and $\mathrm{P}$ compounds [57].

The analysis of the seasonal changes revealed lower activity of most enzymes in autumn than in spring. This may be related to weather conditions and seasonal dynamics of soil nutrient content $[64,65]$. An increase in urease activity was detected only in the soils sown with a mixture of grasses and in the control plot in the second term of analyses. A similar tendency was observed in the content of N-NH4+. Nitrogen is taken up by plants and soil microorganisms in the ammonium form (N-NH4+). When large amounts of N-NH4+ are available, the utilization of alternative $\mathrm{N}$ sources, e.g., nitrates $\left(\mathrm{N}-\mathrm{NO}_{3}{ }^{-}\right)$, is generally inhibited. In turn, at low availability of $\mathrm{N}-\mathrm{NH} 4+$, enzymatic systems for utilization of alternative $\mathrm{N}$ sources are activated, and the presence of a substrate induces their synthesis [66].

The present results confirm the idea that enzymatic activity is one of the most important parameters of the biological status of the soil environment, as it is a measure of soil fertility and quality as well as ecosystem biodiversity $[19,20,62,67]$. The cited authors highlight the close relationship of soil enzymes with many important physicochemical and biological parameters, e.g., reaction, organic matter content, biological activity, and microbial biomass content. Dehydrogenases are commonly found in organic matter-rich soils, and they are regarded as good indicators of the respiratory metabolism of microbes [20,62]. Nannipieri et al. [68] have reported that phosphatases stimulate the conversion of organic phosphorus compounds into inorganic phosphates, while ureases are involved in ammonification, during which ammonia is released from urea, amino acids, and purine bases. Deer excrements in the soil environment are a source of organic matter, macro- and microelements, and enzymes, which are secreted by numerous species of bacteria and fungi present in urine and feces. Feces are also a unique food for hundreds of species of invertebrate coprophages. Animal excrements are also used by many species of e.g., flowering plants visited by many species of wasps, butterflies, and flies. Properly conducted grazing can improve the living conditions of deer and other species of wild fauna through promotion of plant species diversity. At a low level of grazing or postponed grazing, pastures may be dominated by seasonal perennials outcompeting species that are important for deer. Livestock grazing can improve the diversity of herbaceous plants by compaction of the soil and thinning dense tree stands or shrubs [69]. The results reported by Santalahti et al. [70] showed that reindeer grazing altered the fungal community structure and enhanced extracellular enzyme activities related to degradation of cellulose and hemicelluloses and nutrient acquisition from the needle litter in northern boreal forest soils. Reindeer grazing increased the estimated species richness but had no significant 
effect on soil fungal diversity [70]. Li et al. [50] reported that the vegetation height, coverage, and above-ground biomass significantly declined with increased grazing intensity, but the species richness reached the highest level in a moderate grazing intensity meadow. The species composition in the vegetation cover, in turn, has an impact on the accumulation of specific substrates for enzymatic reactions in the soil. The influence of higher plants on soil enzymes depends on the chemical composition of the plant, which may differ between different genera, species, and varieties, even in the case of root exudates [51,71]. In turn, as suggested by Herold et al. [57], microbial biomass and its structure as well as enzyme activity are dependent on soil parameters to a greater extent than on the type of use of meadows.

\section{Conclusions}

Each type of soil has a characteristic composition of specific enzymes and a specific level of enzymatic activity. Analyses of the activity of a number of soil enzymes facilitate unique and integrative assessment of the ecobiochemical status of soils in terms of the dynamics of changes induced by anthropogenic factors in ecosystems. As mentioned in the introduction, the world scientific literature does not provide information about the impact of cervid grazing on the biochemical properties of soil. Assessment of soil quality is not easy due to the complexity of the soil environment and the variability of the conditions prevailing therein. The results of the present pilot study have demonstrated a positive effect of cervid grazing on the biochemical parameters of the soil environment. The results may help to design future programs for assessment of soil quality and health and the biodiversity in pastures for livestock, including farmed cervids. Nevertheless, the full and objective characterization of environmental processes requires long-term monitoring.

Author Contributions: Conceptualization: B.F. and K.T.; methodology: B.F., K.T., L.D. and T.M.G.; formal analysis: B.F., K.T., L.D. and T.M.G.; investigation: Ż.S.-B.; writing-original draft preparation: B.F. and K.T.; writing-review and editing: B.F. and K.T. supervision: B.F. and K.T. All authors have read and agreed to the published version of the manuscript.

Funding: This work was supported by BIOSTRATEG2/297267/14/NCBR/2016.

Institutional Review Board Statement: Not applicable.

Informed Consent Statement: Not applicable.

Data Availability Statement: Not applicable.

Conflicts of Interest: The authors declare that they have no known competing financial interests or personal relationships that could have appeared to influence the work reported in this paper.

\section{References}

1. Jeffery, S.; Gardi, C. Soil biodiversity under threat-A review. Acta Soc. Zool. Bohem. 2010, 74, 7-12.

2. Akçakaya, H.; Butchart, S.; Watson, J.; Pearson, R. Preventing species extinctions resulting from climate change. Nat. Clim. Chang. 2014, 4, 1048-1049. [CrossRef]

3. Metera, E.; Sakowski, T.; Sloniewski, K.; Romanowicz, B. Grazing as a tool to maintain biodiversity of grassland-A review. Anim. Sci. Pap. Rep. 2010, 28, 315-334.

4. Tiainen, J.; Hyvönen, T.; Hagner, M.; Huusela-Veistola, E.; Louhi, P.; Miettinen, A.; Nieminen, T.; Palojärvi, A.; Seimola, T.; Taimisto, P.; et al. Biodiversity in intensive and extensive grasslands in Finland: The impacts of spatial and temporal changes of agricultural land use. Agric. Food Sci. 2020, 29, 68-97. [CrossRef]

5. Futa, B.; Patkowski, K.; Bielińska, E.J.; Gruszecki, T.M.; Pluta, M.; Kulik, M.; Chmielewski, S. Sheep and horse grazing in a large-scale protection area and its positive impact on chemical and biological soil properties. Pol. J. Soil Sci. 2016, 49, 111-122. [CrossRef]

6. Ross, L.C.; Austrheim, G.; Asheim, L.J.; Bjarnason, G.; Feilberg, J.; Fosaa, A.M.; Hester, A.J.; Holand, Ø.; Jónsdóttir, I.S.; Mortensen, L.E.; et al. Sheep grazing in the North Atlantic region: A long-term perspective on environmental sustainability. Ambio 2016, 45, 551-566. [CrossRef]

7. Chabuz, W.; Kulik, M.; Sawicka-Zugaj, W.; Żółkiewski, P.; Warda, M.; Pluta, M.; Lipiec, A.; Bochniak, A.; Zdulski, J. Impact of the type of use of permanent grasslands areas in mountainos regions on the floristic diversity of habitats and animal welfare. Glob. Ecol. Conserv. 2019, 19, e00629. [CrossRef] 
8. Patkowski, K.; Pluta, M.; Lipiec, A.; Greguła-Kania, M.; Gruszecki, T.M. Foraging behavior patterns of Sheep and horses under a mixed species grazing system. J. Appl. Anim. Welf. Sci. 2019, 22, 357-363. [CrossRef]

9. Hao, Y.; He, Z. Effects of grazing patterns on grassland biomass and soil environments in China: A meta-analysis. PLoS ONE 2019, 14, e0215223. [CrossRef] [PubMed]

10. Kulik, M.; Warda, M.; Gawryluk, A.; Bochniak, A.; Patkowski, K.; Lipiec, A.; Gruszecki, T.M.; Pluta, M.; Bielińska, E.J.; Futa, B. Grazing of native livestock breeds as a method of grassland protection in Roztocze National Park, Eastern Poland. J. Ecol. Eng. 2020, 21, 61-69. [CrossRef]

11. Schmitz, A.; Isselstein, J. Effect of grazing system on grassland plant species richness and vegetation characteristics: Comparing horse and cattle grazing. Sustainability 2020, 12, 3300. [CrossRef]

12. Schieltz, J.M.; Rubenstein, D.I. Evidence based review: Positive versus negative effects of livestock grazing on wildlife. What do we really know? Environ. Res. Lett. 2016, 11, 113003. [CrossRef]

13. Lai, L.; Kumar, S. A global meta-analysis of livestock grazing impacts on soil properties. PLoS ONE 2020, 15, e0236638. [CrossRef]

14. Golluscio, R.A.; Austin, A.T.; Martínez, G.G.C.; González-Polo, M.; Sala, O.E.; Jackson, R.B. Sheep grazing decreases organic carbon and nitrogen pools in the patagonian steppe: Combination of direct and indirect effects. Ecosystems 2009, 12, 686-697. [CrossRef]

15. Eldridge, D.J.; Poore, A.G.; Ruiz-Colmenero, M.; Letnic, M.; Soliveres, S. Ecosystem structure, function, and composition in rangelands are negatively affected by livestock grazing. Ecol. Appl. 2016, 26, 1273-1283. [CrossRef]

16. Bartoš, L.; Šiler, J. Survey of Game Farming in Europe; FAO: Rome, Italy, 1993.

17. Fletcher, T.J. The domestication and husbandry of deer in tropical regions. Trop. Agric. Assoc. Newsl. 2002, 22, 3-7.

18. Reinken, G. Deer Farming: A Practical Guide to German Techniques; Farming Press Books: Ipswich, UK, 1990.

19. Siwik-Ziomek, A.; Lemanowicz, J. The influence of fertilization with phosphorus, sulphate, carbon and nitrogen content on hydrolases activities in soil. Pol. J. Soil Sci. 2016, 49, 49-60. [CrossRef]

20. Nannipieri, P.; Trasar-Cepeda, C.; Dick, R.P. Soil enzyme activity: A brief history and biochemistry as a basis for appropriate interpretations and meta-analysis. Biol. Fertil. Soils 2017, 54, 11-19. [CrossRef]

21. Futa, B.; Oleszczuk, P.; Andruszczak, S.; Kwiecińska-Poppe, E.; Kraska, P. Effect of natural aging of biochar on soil enzymatic activity and physicochemical properties in long-term field experiment. Agronomy 2020, 10, 449. [CrossRef]

22. Dick, R.P. Methods of Soil Enzymology; SSSA Book Series 9; Soil Science Society of America Inc.: Madison, WI, USA, 2011.

23. Bastida, F.; Zsolnay, A.; Hernández, T.; Garcia, C. Past, Present and future of soil quality indices: A biological perspective. Geoderma 2008, 147, 159-171. [CrossRef]

24. Nortcliff, S. Standardisation of soil quality attributes. Agric. Ecosyst. Environ. 2002, 88, 161-168. [CrossRef]

25. Skowrońska, M.; Bielińska, E.J.; Szymański, K.; Futa, B.; Antonkiewicz, J.; Kołodziej, B. An integrated assessment of the long-term impact of municipal sewage sludge on the chemical and biological properties of soil. Catena 2020, 189, 104484. [CrossRef]

26. Mattiello, S. Welfare issues of modern deer farming. Ital. J. Anim. Sci. 2009, 8, 205-217. [CrossRef]

27. Falandysz, J.; Szymczyk-Kobrzyńska, K.; Brzostowski, A.; Zalewski, K.; Zasadowski, A. Concentrations of heavy metals in the tissues of red deer (Cervus elaphus) from the region of Warmia and Mazury, Poland. Food Addit. Contam. 2005, 22, 141-149. [CrossRef]

28. KOSEWOPAN. Available online: http:/ / kosewopan.pl/pl/hodowla/ (accessed on 22 February 2021).

29. The Federation of European Deer Farmers Associations 2021 (FEDFA). Available online: https://www.fedfa.com/en/fedfamembers/\#1364 (accessed on 22 February 2021).

30. Pawelec, W.; Wereski, S. (Eds.) Bulletin of the National Hydrological and Meteorological Service 2018; Institute of Meteorology and Water Management-National Research Institute: Gdynia, Poland, 2019; Volume 13, p. 202.

31. Statistics Poland. Environment; Statistics Poland: Warsaw, Poland, 2019.

32. IUSS Working Group WRB. World Reference Base for Soil Resources 2014, Update 2015. International Soil Classification System for Naming Soils and Creating Legends for Soil Maps; Report No. 106; FAO: Rome, Italy, 2015.

33. Tajchman, K.; Bogdaszewski, M.; Kowalczuk-Vasilev, E. Effects of suplementation with different levels of calcium and phosporus on mineralcontent of first antler, bone, muscle, and liver of farmed fallow deer (Dama dama). Can. J. Anim. Sci. 2020, 100, 17-26. [CrossRef]

34. International Organization for Standardization. Soil Quality. Sampling; ISO 18400; ISO: Geneva, Switzerland, 2018. [CrossRef]

35. International Organization for Standardization. Soil Quality. Determination of pH; ISO 10390; ISO: Geneva, Switzerland, 2005.

36. International Organization for Standardization. Soil Quality-Determination of Nitrate Nitrogen, Ammonium Nitrogen and Total Soluble Nitrogen in Air-Dry Soils Using Calcium Chloride Solution as Extractant; ISO 14255; ISO: Geneva, Switzerland, 1998.

37. International Organization for Standardization. Soil Quality. Determination of Total Nitrogen Content by Dry Combustion; ISO 13878; ISO: Geneva, Switzerland, 1998.

38. International Organization for Standardization. Soil Quality. Determination of Organic Carbon by Sulfochromic Oxidation; ISO 14235; ISO: Geneva, Switzerland, 1998.

39. Polish Committee for Standardization. Agrochemical Soil Analisye-Determination of Assimilated Phosphorus Content; PN-R-04023; ISO: Geneva, Switzerland, 1996. 
40. Polish Committee for Standardization. Agrochemical Soil Analisye-Determination of Assimilated Potasium Content; PN-R-04022; ISO: Geneva, Switzerland, 1996.

41. Polish Committee for Standardization. Agrochemical Soil Analisye-Determination of Assimilated Magnesium Content; PN-R-04020; ISO: Geneva, Switzerland, 1994.

42. Schinner, F.; Ohlinger, R.; Kandeler, E.; Margesin, R. Methods in Soil Biology; Springer: Berlin/Heidelberg, Germany, 1995.

43. Franzluebbers, A.J. Soil organic master stratification ratio as an indicator of soil quality. Soil Tillage Res. 2002, 66, 95-106. [CrossRef]

44. Xin, G.S.; Long, R.J.; Guo, X.S.; Irvine, J.; Ding, L.M.; Ding, L.L.; Shang, Z.H. Blood mineral status of grazing Tibetan sheep in the Northeast of the Qinghai-Tibetan Plateau. Livest. Sci. 2011, 136, 102-107. [CrossRef]

45. Głowacz, K.; Niżnikowski, R. The effect of animal grazing on vegetation and soil and element cycling in nature. Environ. Sci. Pollut. Res. Int. 2018, 25, 3565-3570. [CrossRef]

46. Vilela, M.d.O.; Gates, R.S.; Souza, C.F.; Teles, C.G.S., Jr.; Sousa, F.C. Nitrogen transformation stages into ammonia in broiler production: Sources, deposition, transformation, and emission into the environment. DYNA 2020, 87, 221-228. [CrossRef]

47. Abrahams, P.W.; Steigmajer, J. Soil ingestion by sheep grazing in the metal enriched floodplain soils of Mid Wales. Environ. Geochem. Health 2003, 25, 17-26. [CrossRef] [PubMed]

48. Ano, A.; Ubochi, C. Neutralization of soil acidity by animal manures: Mechanism of reaction. Afr. J. Biotechnol. 2010, 6, 364-368. Available online: https:/ / www.ajol.info/index.php/ajb/article/view/56212 (accessed on 22 February 2021).

49. Liu, N.; Zhang, Y.; Chang, S.; Kan, H.; Lin, L. Impact of grazing on soil carbon and microbial biomass in typical steppe and desert steppe of inner mongolia. PLoS ONE 2012, 7, e36434. [CrossRef]

50. Li, W.; Huang, H.Z.; Zhang, Z.N.; Wu, G.L. Effects of grazing on the soil properties and C and N storage in relation to biomass allocation in an alpine meadow. J. Soil Sci. Plant. Nutr. 2011, 11, 27-39. [CrossRef]

51. Bielińska, E.J.; Futa, B.; Chmielewski, S.; Patkowski, K.; Gruszecki, T. Quantification of biodiversity related to the active protection of grassland habitats in the eastern Lublin region of Poland based on the activity of soil enzymes. Pol. J. Soil Sci. 2017, 50, 55-62. [CrossRef]

52. Galindo, F.S.; Delate, K.; Heins, B.; Phillips, H.; Smith, A.; Pagliari, P.H. Cropping system and rotational grazing effects on soil fertility and enzymatic activity in an integrated organic crop-livestock system. Agronomy 2020, 10, 803. [CrossRef]

53. Nahm, K. Evaluation of the nitrogen content in poultry manure. Worlds Poult. Sci. J. 2003, 59, 77-88. [CrossRef]

54. Gay, S.W.; Knowlton, K.F. Ammonia emission and animal agriculture. Biol. Sys. Eng. 2005, 110-442.

55. Hoogendoorn, C.J.; Betteridge, K.; Ledgard, S.F.; Costall, D.A.; Park, Z.A.; Theobald, P.W. Nitrogen leaching from sheep-, cattleand deer-grazed pastures in the Lake Taupo catchment in New Zealand. Anim. Prod. Sci. 2011, 51, 416-425. [CrossRef]

56. Bielińska, E.J.; Mocek-Płóciniak, A. Biochemical and chemical indices of soil transformations on goose farms in years 1996-2011. Arch. Environ. Prot. 2015, 41, 84-89. [CrossRef]

57. Herold, N.; Schöning, I.; Gutknecht, J.; Alt, F.; Boch, S.; Müller, J.; Oelmann, Y.; Socher, A.S.; Wilcke, W.; Wubet, T.; et al. Soil property and management effects on grassland microbial communities across a latitudinal gradient in Germany. Appl. Soil Ecol. 2014, 73, 41-50. [CrossRef]

58. Qin, Y.; Niu, D.; Kang, J.; Zhou, Y.; Li, X. Effects of livestock exclusion on soil physical and biochemical properties of a desert rangeland. Pol. J. Environ. Stud. 2015, 24, 2587-2595. [CrossRef]

59. Burke, D.; Weintraub, M.; Hewins, C.; Kalisz, S. Relationship between soil enzyme activities, nutrient cycling and soil fungal communities in a northern hardwood forest. Soil Biol. Biochem. 2011, 43, 795-803. [CrossRef]

60. Nannipieri, P.; Giagnoni, L.; Landi, L.; Renella, G. Role of phosphatase enzymes in soil. Soil Biol. 2011, 26, $215-243$.

61. Dick, W.A.; Cheng, L.; Wang, P. Soil acid alkaline phosphatase activity as pH adjustment indicators. Soil Biol. Biochem. 2000, 32, 1915-1919. [CrossRef]

62. Ingram, L.J.; Stahl, P.D.; Schuman, G.E.; Buyer, J.S.; Vance, G.F.; Ganjegunte, G.K.; Welker, I.M.; Derner, I.D. Grazing impacts on soil carbon and microbial communities in a mixed-grass ecosystem. Soil Sci. Soc. Am. J. 2008, 72, 38. [CrossRef]

63. Acosta-Martínez, V.; Bell, C.W.; Morris, B.E.L.; Zak, J.; Allen, V.G. Long-term soil microbial community and enzyme activity responses to an integrated cropping-livestock system in a semi-arid region. Agric. Ecosyst. Environ. 2010, 137, 231-240. [CrossRef]

64. Deng, J.; Chong, Y.; Zhang, D.; Ren, C.; Zhao, F.; Zhang, X.; Han, X.; Yang, G. Temporal variations in soil enzyme activities and responses to land-use change in the Loess Plateau. China Appl. Sci. 2019, 9, 3129. [CrossRef]

65. Zuccarini, P.; Asensio, D.; Ogaya, R.; Sardans, J.; Peñuelas, J. Effects of seasonal and decadal warming on soil enzymatic activity in a P-deficient Mediterranean shrubland. Glob. Chang. Biol. 2020, 26, 3698-3714. [CrossRef]

66. Geisseler, D.; Horwath, W.R.; Joergensen, R.G.; Ludwig, B. Pathways of nitrogen utilization by soil microorganisms-A review. Soil Biol. Biochem. 2010, 42, 2058-2067. [CrossRef]

67. Samuel, S.D.; Brejea, R.; Domuta, C.; Bungau, S.; Cenusa, N.; Tit, D.M. Enzymatic indicators of soil quality. J. Environ. Prot. Ecol. 2017, 18, 871-878.

68. Nannipieri, P.; Ascher, J.; Ceccherini, M.T.; Landi, L.; Pietramellara, G.; Renella, G. Microbial diversity and soil functions. Eur. J. Soil Sci. 2003, 54, 655-670. [CrossRef]

69. Richardson, C.; Lionberger, J.; Miller, G. White-Tailed Deer Management in the Rolling Plains of Texas; Wildlife Biologists Texas Parks and Wildlife Department: Austin, TX, USA, 2008. 
70. Santalahti, M.; Sun, H.; Sietiö, O.; Köster, K.; Berninger, F.; Laurila, T.; Pumpanen, J.; Heinonsalo, J. Reindeer grazing alter soil fungal community structure and litter decomposition related enzyme activities in boreal coniferous forests in Finnish Lapland. Appl. Soil Ecol. 2018, 132, 74-82. [CrossRef]

71. Błońska, E.; Lasota, J.; Zwydak, M. The relationship between soil properties, enzyme activity and land use. For. Res. Pap. 2017, 78, 39-44. [CrossRef] 